\title{
FORUM ON CREATIVE TEACHING
}

The inclusion in Horizons of a forum on creative teaching reflects the particular character of the College Theology Society as an association of teachers. While most members probably belong to one or more learned societies relevant to their specialized interests, membership in the CTS represents an additional, and perhaps fundamental, concern with teaching as such. This forum is designed to provide an exchange of ideas and materials among teachers through description and discussion of actual courses being taught.

The course descriptions published this year, though different from one another in approach, are similar in their attempt to deal with religious realities through the use of literary materials. Elena Malits' "Theology as Biography" in this issue and John Miles' "Bildungsromane and the Pedagogy of Comparative Religion" in the next correspond to the efforts many teachers are making to break away from narrow, abstracted notions of religion by concentrating on personal and concrete experience. Whether in actual or fictional story, the endeavor is to understand religion as a power or motivating force in human lives. The endeavor is reflection on experience, which is after all prior to system and doctrine, in order to discern its contours and patterns of meaning: it is to study the way images and symbols shape and form religion, as well as the way religion shapes and forms individual human lives. Such studies are not removed from system and doctrine, for personal story or experience inevitably occurs within the collective religious stories of mankind. But such stories serve to demonstrate the irreducibly personal and original creation that is the life of every religious figure, the unique interpretation and assimilation of traditional (and not so traditional) religious and cultural patterns.

This turn to the concrete experience beyond or behind formalized theology has been criticized from several quarters. Some see it as a fad, or as an attempt to popularize, which, avoiding the serious intellectual labor of analyzing, criticizing, synthesizing turns from the careful objectivity of theology to an idiosyncratic undiscipline. To others, it appears to concentrate the study of religion on inner, personal experience at the expense of "outer" religious expression, social concern and political responsibility.

The testimony of those who have worked in sustained fashion with such courses, however, has demonstrated the opposite to be true. It quickly becomes apparent that personal stories present an immediate challenge to the critical powers of the student and the teacher of religion. As incarnate examples of religious experience, stories in fact demand disciplined analysis, definition of the terms 
and the categories of "religious" discussion, and careful clarification of symbolic worlds of meaning. In short, they lead directly into recognition of the theological or religious framework that is implicit in the experience of religious people. Moreover, in an analysis of such broader patterns of religious meaning, the ineluctable unity of inner experience and outward expression can be discerned. For example, in one of the most interesting and influential "lives" of the recent American Catholic past, Thomas Merton, it is an intriguing theological study to observe the changing relationship of an intense interior life to "the world" developing from Seven Storey Mountain through The Sign of Jonas to Conjectures of a Guilty Bystander. Here, the reader's attempt to account for the striking differences in standpoint throughout Merton's history leads easily to a discussion of several Catholic theological worlds in their presuppositions and concrete implications. Another rich source for study is Dorothy Day, whose story vividly illustrates the same problematic of religious experience and social responsibility. Examples can be multiplied which demonstrate the relationship between theory and life, between inner and outer, between personal experience and social or religious context.

Careful selection is important as one sets out to find those materials, biographical or fictional, which are appropriate for properly religious analysis and for the particular perspective of a given course. But the serious effort is a significant contribution to the undergraduate study of religion today. Following the reflections of Bernard Lonergan on differentiated consciousness and levels of meaning in the study of religion, to focus on interiority and self-transcendence (as the ground of common sense and theory), and the meaning of religious "conversion," is to approach the foundations of religion in its personal and communal reality. Such studies, then, provide a fruitful introduction to the phenomenon of religion as well as an opportunity for an advanced step into such issues as religious pluralism and theological method. Finally, and not least important, they provide intrinsically engaging material for religious inquiry and criticism-the complexities and tangles of real life. 